\title{
Factors Affecting Employability Skills of Beauty Students in Gerbang Kertosusila
}

\author{
Amina Ningsih*, Eko Hariadi, Marniati, \& Tri Rijanto \\ Department of Technology and Vocational Education, Postgraduate of State University of Surabaya, Surabaya, 60213, \\ Indonesia. \\ aminaningsih16070895035@mhs.unesa.ac.id; ekohariadi@unesa.ac.id; marniati@unesa.ac.id, tririjanto@unesa.ac.id \\ *Corresponding Author: aminaningsih16070895035@mhs.unesa.ac.id | Phone Number: +6285655817379
}

\begin{abstract}
There is currently an imbalance between the skills mastered by vocational high school graduates with the skills needed in the labor market, especially employability skills, to maintain a job in various conditions and job requirements. This study aimed to examine the factors that affecting the employability skills of Beauty students namely career guidance, fieldwork practices, emotional intelligence, and self-efficacy. The respondents consisted of 254 students in Beauty Expertise Program at Gerbang Kertosusila. The instruments used in this study were questionnaire with a Likert scale and the statistical method using structural equation modeling (SEM). This study found no significant effect of career guidance, fieldwork practice, emotional intelligence, and self-efficacy on employability skills among Beauty students. The study also showed that career guidance and emotional intelligence have no significant effect on self-efficacy. However, fieldwork practice has a significant effect on the self-efficacy of Beauty students.
\end{abstract}

Keywords: employability skills; career guidance; fieldwork practice; emotional intelligence; self-efficacy;

\section{Introduction}

The presence of the ASEAN Economic Community and the industrial revolution 4.0 have become a significant challenge for ASEAN member countries, including Indonesia, to become more competitive in human resources and employment. Several sectors have been openly agreeing to head towards the ASEAN 2020 Vision's economic vision, one of which includes skin and hair beauty (BNSP, 2017). Currently, the skin and hair beauty industry wants a standardized and professional workforce (BNSP, 2017). Thus educational institutions need to make every effort to improve graduates' competitiveness (Herwina, Madjid, \& Daniel, 2018), primarily vocational high schools, which have a role in preparing graduates to go directly into the world of work. Yet the facts show that the implementation of vocational education has not been achieved, and vocational high school graduates are still unable to satisfy the workforce's demands according to their expertise (Munadi et al., 2018). The Central Statistics Agency conveyed data that in February 2020, the highest unemployment rate in East Java was held by Vocational High School graduates, by 8.04 percent (BPS, 2020). Many factors cause vocational school graduates to still not getting a job after graduating (Fitriyanto \& Pardjono, 2019). One of them is because there is an imbalance between the skills mastered by vocational high school graduates with the skills needed in the labor market, especially employability skills to maintain a job in various conditions and job requirements (Hanafi, 2012).

Juhdi et al. (2010) state that today, employers are looking for employees who have technical skills and can carry out various tasks and roles. In line with Husain et al. (2010), who states that if graduates want to become competent employees, they need to have two primary skills: specific skills and employability skills. Specific skills are skills from a discipline intended to be used in particular work fields (Bridgstock, 2011; Zakaria, Yatim, \& Ismail, 2014). In comparison, employability skills are work skills or generic skills required to be applied to various work types and are prepared to enter work (Munadi et al., 2018). Employability is a set of skills that enhance graduates to getting a job and implies something about a graduate's capacity to function in a job and move between positions so that they can remain employed throughout their life (Brewer, 2013). The employability skills attribute such as thinking critically, communicating effectively, having the strength and enthusiasm to continue learning, and working in teamwork (Brewer, 2013). In other 
words, employability skills are skills specifically related to working for a person in various situations.

Graduates with high employability skills will have a greater chance of getting a job and succeeding in their career because they are prepared and able to withstand various job challenges. Therefore, vocational high school graduates need to be given more opportunities to develop employability skills attributes in addition to technical skills (Amiruddin, Sunardi, \& Irmayanti, 2013). Jun (2017) revealed that graduates' employability skills could come from external and individual factors. Several studies also have identified factors that affect and enhance students' employability skills, such as Tentama \& Merdiaty (2020), Fitriyanto \& Pardjono (2019), and Yahya, Iskandar, \& Sunardi (2017). But further investigation on previous studies revealed that although a lot of literature discusses employability skills, there is still not much research conducted to empirically support employability skills for vocational high school students in Indonesia, especially students who were majoring in Beauty Expertise Program. Therefore, our study came to enrich knowledge about employability skills. This study aimed to examine the factors that affect students' employability skills of the Beauty Expertise Program at Gerbang Kertosusila. Factors that were examined are career guidance, fieldwork practices, emotional intelligence, and self-efficacy.

\section{Literature Review}

\subsection{Employability Skills}

Employability skills are a set of attributes, skills, and knowledge that all labor market participants must possess to ensure they have the ability to be effective in the workplace, for the benefit of themselves, their bosses, and the wider community (CBI, 2011). In line with Munadi et al. (2018) who define employability skills as work skills or various generic skills required to be applied to multiple types of work and are prepared to enter jobs. Employability skills are considered very important because current job characteristics require one's initiative, flexibility, and ability to handle different tasks (Sunardi, Purnomo, \& Sutadji, 2016).

Previous studies had provide the concept of employability dimensions, such as Yorke \& Knight (2003), which succeeded in developing the USEM model. The USEM model describes employability skills as four broad and interrelated components: understanding, skills or practical skills, efficacy beliefs, and metacognition (Yorke, 2010; Yorke \& Knight, 2003). Meanwhile, Pool \& Sewell (2007) suggested the CareerEDGE model to describes graduates' employability skills. CareerEDGE model outlines the key factors that can enhance graduates' employability skills, namely career development learning, work \& life experience, degree subject knowledge, understanding \& skills, generic skills, and emotional intelligence.

According to Munadi et al. (2018), there are several aspects of employability skills that vocational high school graduates must have based on opinions from the industry. These aspects include communication, teamwork, problem-solving, initiative and entrepreneurial skills, planning and organizing activities, selfmanagement, learning, using technology, and occupational health and safety. Graduates also need to emphasize personal qualities and leadership skills (Rasul et al., 2013). By having these various skills, graduates will be able to face every challenge in the workplace.

\subsection{Career Guidance}

Career guidance is guidance to prepare students for the world of work, choose a specific job field or profession, equip themselves to do the job, and adapt to various positions (Winkel \& Hastuti, 2015). In general, the goal of career guidance is to help students make decisions based on their interests, passions, and abilities while taking into account current and future career opportunities (Loan \& Van, 2015). Career guidance was found to have the strongest association and plays a vital role with other components of employability skills to achieve desired goals (Pitan \& Atiku, 2017). Career guidance plays a role in increasing students' employability skills, especially in developing essential professional skills in the labor market, enhancing professional career management, and facilitating them to access jobs that meet their needs expectations (Martínez-roca, Martínez, \& Pineda, 2014). Other research results also support the finding that career guidance has a positive and significant effect on employability skills (Kurniawati \& Arief, 2016; Cahyono, 2014). Career guidance can be a powerful solution to reducing youth unemployment concerning technical and vocational education (TVE) and entrepreneurship (Afujo, 2013).

\subsection{Fieldwork Practice}

Fieldwork practice is a professional preparation process in which students who will soon formally complete their studies work in the field supervised by a competent administrator for a certain period, which is intended to improve their ability to carry out their responsibilities (Hamalik, 2009). Through fieldwork practices, students can learn from their experiences in the world of work to develop competencies and skills and increase their employability skills. Guile \& Griffiths (2016) revealed that fieldwork practices contributed significantly to developing student work skills. Compared with academic achievement, fieldwork practice programs' involvement significantly affects graduates' employability and quality of life skills (Eden, 2017). It 
is also widely agreed that graduates with work experience are more likely to find jobs than graduates who are not (Pegg et al., 2012). Many of the attributes of the employability skills that job recruiters are looking for can only be learned from real-life situations (Weldon \& Ngo, 2019). Several other studies also support the statement that fieldwork practices have contributed significantly to developing students' employability skills (Subekti \& Ana, 2018; Dwesini, 2017; Anas \& Hamzah, 2017; Helyer \& Lee, 2015).

\subsection{Emotional Intelligence}

The criteria for success in the workplace are changing. Employees are judged not only by how smart they are or by their training and skills but also by how well they handle themselves and others (Serrat, 2009). Emotional intelligence is the ability to reason legally with emotions and with information related to emotions and to use these emotions as guidelines for thinking and behaving (Mayer, Caruso, \& Salovey, 2016). Emotional intelligence nowadays plays a role in employment initiatives, including employee recruitment and placement, job performance, and job satisfaction (Pathak, Shankar, \& Tewari, 2018). Simonis (2010) reveals that what companies are looking for in new employees is emotional intelligence because they can face problems more efficiently and are more productive (Kannaiah \& Shanthi, 2015). Several studies have also revealed that emotional intelligence has a powerful influence on students' employability skills (Coetzee \& Beukes, 2010; Jayawardena \& Gregar, 2013; Potgieter \& Coetzee, 2013; Navas, 2014). Thus if students can manage and regulate emotions in themselves and others, it can help them get a job (Xu, 2013).

\subsection{Self-Efficacy}

Self-efficacy is an individual's belief in his or her ability to regulate and take actions that are deemed necessary to manage situations that may occur (Bandura, 2006; Bandura, 1997). The essence of self-efficacy theory means that the action to initiate something, as well as persistence in behavior and action, is all determined primarily by individual assessments and expectations regarding skills, behavioral abilities, and the possibility of himself to succeed in overcoming environmental demands and challenges (Maddux, 1995). Previous research has shown that career guidance, fieldwork practices, and emotional intelligence can promote self-efficacy (Restubog, Florentino, \& Garcia, 2016; Edwards, 2014; Tabatabaei et al., 2013).

Moreover, self-efficacy has been associated with the challenge of employability skills (Rawat \& Sharma, 2018). Sources of self-efficacy that are relevant to employability skills are mastery experience, vicarious experience, and social persuasion (Rufai, Bakar, \& Rashid, 2015; Freudenberg, Brimble, \& Cameron, 2010; Bandura, 1995). Van de Hof (2015) state that high self-efficacy of graduates will lead to high employability skills as well. Because in an increasingly challenging job market, higher levels of self-efficacy play a key role in translating education into employability skills (Quiring, Boys, \& Harris, 2017).

Therefore, the hypotheses in this study are:

H1: Career guidance affect employability skills.

H2: Fieldwork practice affect employability skills.

H3: Emotional intelligence affect employability skills.

H4: Self-efficacy affect employability skills.

H5: Career guidance affect self-efficacy.

H6: Fieldwork practice affect self-efficacy.

H7: Emotional intelligence affect self-efficacy.

\section{Materials and Methods}

This empirical research was based on a sample of 254 students from class XII of the Skin \& Hair Beauty Expertise Program for the 2020/2021 academic year at Gerbang Kertosusila. Respondents are aged between 17-19 years and are female (100\%). They came from SMKN 1 Sooko Mojokerto, SMKN 8 Surabaya, SMKN 1 Buduran Sidoarjo, and SMKN 1 Lamongan. The data were collected through an online questionnaire formulated as sentences answered on a five-point Likert scale, with 1 (strongly disagree) to 5 (strongly agree). All construction measures are self-developed of the existing hierarchy. We developed a measurement for career guidance from career guidance goals (Supriatna \& Budiman, 2010), fieldwork practice from the benefits of fieldwork practices (Hamalik, 2009), emotional intelligence from the component of emotional intelligence (Goleman, 2001), and self-efficacy from self-efficacy dimension (Bandura, 2006). While employability skills were measured using nine indicators adapted from Munadi et al. (2018). Data were then statistically analyzed through structural equation modeling (SEM). SEM is a multivariate regression that aims to simultaneously explore the structural relationship between several dependent variables and several independent variables (Geiser, 2013). In this study, SEM was used to analyze the effect of career guidance, fieldwork practices, and emotional intelligence on the self-efficacy and employability skills of Beauty students at Gerbang Kertosusila. To estimate SEM, the computer program used in this study was Mplus 7. 


\section{Results and Discussions}

\subsection{Measurement Model}

A measurement model's primary purpose is to describe how well the observed indicator variable serves as a measurement instrument for the underlying latent variable or factor. The measurement model is usually carried out and evaluated by confirmatory factor analysis (CFA). CFA proposes a relationship between the observed indicator variable and the latent variable that has been designed to be measured as a measurement model. The CFA tests these two variables against the data to confirm the proposed factorial structure (Wang \& Wang, 2012). Then, a first-order CFA is tested. Six items are loaded on the dimension career guidance, five items loaded on fieldwork practice, four items loaded on emotional intelligence, three items loaded on selfefficacy, and nine items loaded on employability skills. To assess the model fit, the comparative fit index (CFI), the Tucker-Lewis index (TLI), the root mean square error of approximation (RMSEA), and the standardized root means square residual (SRMR) was examined. Acceptable fit is evidenced by a CFI and TLI of .90 or higher, an RMSEA of .08 or lower, and an SRMR of .08 or lower (Geiser, 2013; Wang \& Wang, 2012). The initial CFA showed acceptable fit indices (CFI=.922; TLI=.913; RMSEA=.042; and SRMR=.050).

The measurement model is evaluated by examining individual item reliability, construct reliability, average variance extracted analysis, and discriminant validity. The measurement model has good reliability if it exceeds the threshold value of 0.7 . In contrast, the reliability of 0.6 to 0.7 can still be accepted with the excellent model's validity (Ghozali, 2017). The results of construct reliability calculations in Table 1 show that all constructs are reliable because they have construct reliability values more than 0.6 . In addition, the items also have satisfactory indicator reliability when each item's loading is at least 0.3 or higher and significant at least at the level of 0.05 (Wang \& Wang, 2012). Based on Table 1, all items loaded significantly on the latent variables $(p<.001)$ with standardized factor loadings ranging from a lower bound of 0.363 to an upper bound of 0.802 . While average variance extracted values for all constructs were higher than 0.5 . Thus, all items used for this study have met the item reliability criteria.

Table 1. Measurement Model

\begin{tabular}{|c|c|c|c|c|}
\hline Measures & Item & Factor Loading & Construct Reliability & $\begin{array}{l}\text { Average Variance } \\
\text { Extracted }\end{array}$ \\
\hline \multirow{6}{*}{ Career Guidance (CG) } & CG1 & 0.688 & 0.72 & 0,63 \\
\hline & CG2 & 0.464 & & \\
\hline & CG3 & 0.497 & & \\
\hline & CG4 & 0.536 & & \\
\hline & CG5 & 0.550 & & \\
\hline & CG6 & 0.535 & & \\
\hline \multirow{5}{*}{ Fieldwork Practice (FP) } & FP1 & 0.722 & 0.85 & 0,80 \\
\hline & FP2 & 0.802 & & \\
\hline & FP3 & 0.755 & & \\
\hline & FP4 & 0.744 & & \\
\hline & FP5 & 0.702 & & \\
\hline \multirow{4}{*}{ Emotional Intelligence (EI) } & EI1 & 0.564 & 0.60 & 0,50 \\
\hline & $\mathrm{EI} 2$ & 0.363 & & \\
\hline & EI3 & 0.621 & & \\
\hline & EI4 & 0.386 & & \\
\hline \multirow{3}{*}{ Self-Efficacy (EFF) } & EFF1 & 0.732 & 0.74 & 0,63 \\
\hline & EFF2 & 0.710 & & \\
\hline & EFF3 & 0.660 & & \\
\hline \multirow{9}{*}{ Employability Skills (EAS) } & EAS1 & 0.765 & 0.88 & 0,78 \\
\hline & EAS2 & 0.720 & & \\
\hline & EAS3 & 0.636 & & \\
\hline & EAS4 & 0.731 & & \\
\hline & EAS5 & 0.688 & & \\
\hline & EAS6 & 0.699 & & \\
\hline & EAS7 & 0.646 & & \\
\hline & EAS8 & 0.457 & & \\
\hline & EAS9 & 0.679 & & \\
\hline
\end{tabular}

\subsection{Analysis of Structural Model}

After the latent factors are assessed in the measurement model, the latent factors' potential relationships are hypothesized and assessed in the structural model. Goodness-of-fit in the structural model test shows the results of acceptable fit indices (CFI=.922; TLI=.913; RMSEA=.042; and SRMR= .050). Meanwhile, to determine the regression coefficient's value between latent factors, it can be seen in Table 2 and Figure 1. Table 2 shows the results of non-standardized regression coefficients for employability skills on the career guidance factor of $\beta=-0.024(t=-0.264, p<0.791)$, indicating that $\mathrm{H} 1$ is rejected. Therefore career guidance 
has no significant effect on employability skills. Meanwhile, the non-standardized regression coefficients for employability skills on the fieldwork practice factor of $\beta=-0.032(\mathrm{t}=-0.397, \mathrm{p}<0.691)$ indicating that $\mathrm{H} 2$ is rejected. Therefore fieldwork practice has no significant effect on employability skills. The non-standardized regression coefficient for employability skills on the emotional intelligence factor of $\beta=-0.024(t=-0.264, p$ $<0.791$ ) indicating that $\mathrm{H3}$ is rejected. Therefore emotional intelligence has no significant effect on employability skills. Whereas non-standardized regression coefficient for employability skills on the selfefficacy factor of $\beta=-0.051(t=-0.572, p<0.567)$, indicating that $\mathrm{H} 4$ is rejected. It means that self-efficacy has no significant effect on employability skills. Table 2 shows the results of non-standardized regression coefficients for self-efficacy on the career guidance factor of $\beta=0.033(t=-0.368, p<0.791)$, indicating that H5 is rejected. Therefore career guidance has no significant effect on self-efficacy. Meanwhile, the nonstandardized regression coefficients for self-efficacy on the fieldwork practice factor of $\beta=-0.182(t=2.006, p$ $<0.045)$ indicating that $\mathrm{H} 6$ is supported. Therefore fieldwork practice has significant effect on self-efficacy. The non-standardized regression coefficient for self-efficacy on the emotional intelligence factor of $\beta=-0.177$ $(t=1.088, p<0.277)$ indicating that $H 7$ is rejected. Therefore emotional intelligence has no significant effect on self-efficacy.

This study's findings do not support the notion that career guidance can improve students' employability skills. Even though various empirical studies have indicated that career guidance assists in implementing measures to support employability skills and has the strongest linkages with all other components of the employability skills (Terzaroli \& Oyekunle, 2019; Buraga \& Caballero, 2018; Pitan \& Atiku, 2017; Martínez-roca et al., 2014). But in this study, career guidance has no significant effect on Beauty students' employability skills. Wang (2012) revealed that although career guidance in schools is provided as part of guidance and counseling, teachers often spend their time dealing with student learning and behavior problems rather than helping most students make their education and vocational choices. However, the vital role of career guidance in schools is to prepare students for the world of work by equipping them with the right skills to remain relevant and fit global economic conditions while leading a meaningful life (Loan \& Van, 2015). Therefore, the entire career subject must be reexamined and perhaps redefined according to their timing and context (Beukes, 2010). The findings in this study are in line with Mutoharoh \& Rahmaningtyas (2019) which found that career guidance did not have a significant effect on work readiness of students. The findings in this study also support the research results of Rosmawati \& Usman (2019) which found that career guidance did not have a significant effect on the employability of vocational high school students majoring in Office Administration Program in South Jakarta.

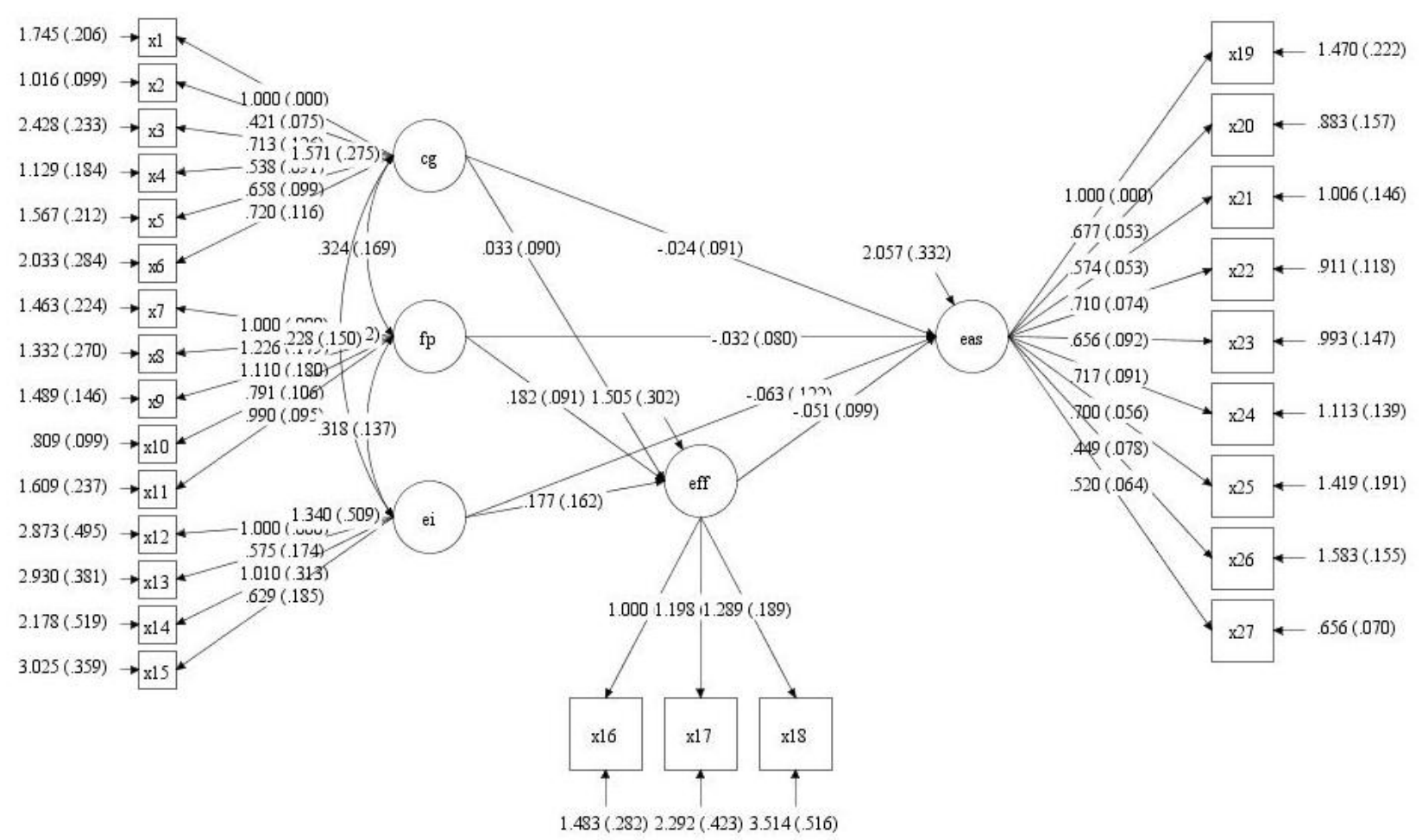

Figure 1. Results of Structural Model 
The present study showed no significant effect of fieldwork practice on employability skills among Beauty students, and $\mathrm{H} 2$ was not supported. The results showed that most Beauty students do not participate in practical fieldwork as one of the primary sources of learning to develop general skills needed in all work types. According to Harvey (2003), employability skills do not automatically exist even though students have attended vocational training. Student participation in traditional fieldwork practice may not reflect students' reasonable goals in the growing world of work (Oliver, 2015). Because only being in a workplace where someone observes or performs menial tasks is unlikely to make a significant difference in employability skills (Oliver, 2015). Whereas Eden (2017) found that work-based learning made students emphasize their learning more in terms of emotional challenges than skills because they were pushed out of their comfort zone. It forced them to be more proactive by handling unfamiliar activities and develop emotionally (Eden, 2017). It's in line with Eccles \& Renaud (2018) that students can build their emotional resilience by managing the stress and challenges experienced during work-based learning. Furthermore, Harry, Chinyamurindi, \& Mjoli (2018) suggest that fieldwork practice is needed to develop employability skills, but it still requires other factors.

Table 2. Hypothesis Testing

\begin{tabular}{lcccc}
\hline \multirow{2}{*}{ 1Hypotheses } & \multicolumn{2}{c}{ Result of the Regression Coefficients between the Latent Factors } \\
\cline { 2 - 5 } & Estimate $(\beta$ value $)$ & t-value & p-value & Decision \\
\hline H1 - CG positively affect EAS & -0.024 & -0.264 & 0.791 & Not supported \\
H2 - FP positively affect EAS & -0.032 & -0.397 & 0.691 & Not supported \\
H3 - EI positively affect EAS & -0.063 & -0.514 & 0.607 & Not supported \\
H4 - EFF positively affect EAS & -0.051 & -0.572 & 0.567 & Not supported \\
H5 - CG positively affect EFF & 0.033 & 0.368 & 0.713 & Not supported \\
H6 - FP positively affect EFF & 0.182 & 2.006 & 0.045 & Supported \\
H7 - EI positively affect EFF & 0.177 & 1.088 & 0.277 & Not supported \\
\hline
\end{tabular}

The H3 of this study was not supported and indicated that emotional intelligence has no significant effect on Beauty students' employability skills. This empirical finding is not consistent with previous studies that showed that emotional intelligence could be used to predict students' employability skills (Potgieter \& Coetzee, 2013; Xu, 2013; Coetzee \& Beukes, 2010). The non-significant results of emotional intelligence may be due to a belief that intellectual intelligence (IQ) is the most determining factor for success, both academically and at work (Singh, 2006). In contrast, emotional intelligence will be learned over time, so formal education has not appropriately taught students about emotional skills such as managing emotions (Goleman, 2009; Zeidner, Matthews, \& Roberts, 2009; Singh, 2006). Jayawardena \& Gregar (2013) state that competitively superior students in potential employability skills tend to have better emotional control. If a person has high emotional intelligence, they can manage their emotions well and work in an excellent mood $(\mathrm{Xu}, 2013)$. Emotional intelligence accounts for $58 \%$ of job performance in all occupational sectors (Jameson $e t$ al., 2016). Therefore, emotional intelligence needs to be considered integrated as an educational strategy to develop the attributes of students' employability skills, especially in a world of work that is continually changing, increasingly uncertain, and volatile (Navas, 2014; Potgieter \& Coetzee, 2013).

The H4 of this study was not supported and indicated that self-efficacy has no significant effect on Beauty students' employability skills. This study's results are different from previous studies that state that self-efficacy contributes to the development of students' employability skills. In this study, most of the Beauty students lacked confidence that they could handle any unexpected situations. According to Pool \& Sewell (2007), everything students do during their schooling will impact self-efficacy, and through the development of high self-efficacy, it can achieve employability skills. So focusing on self-efficacy, increasing student self-awareness, and strengthening self-confidence is essential things to do (Ojonugwa et al., 2015). For example, offering students the opportunity to participate in project planning, public speaking, and consulting with external agencies can improve their self-efficacy and perceived employability (Chow, Wong, \& Lim, 2019). Meanwhile, Berntson, Naswall, \& Sverke (2008) found that employability skills are not an expression of self-efficacy. Instead, strengthening perceptions of employability skills may have a beneficial effect on self-efficacy more generally (Berntson et al., 2008).

This current research has shown that career guidance has no significant effect on self-efficacy. This empirical finding is not consistent with previous studies that indicated that career guidance could promote self-efficacy (Restubog, Florentino, \& Garcia, 2016; Robertson, 2013; Rhode, 2010). The non-significant results of career guidance may be due to career guidance services provided to students have not focused on strategies to increase self-efficacy. Therefore, students' career guidance services should increase self-efficacy through responses to successful student performance achievement, learning modeling or observation, managing anxiety, and providing verbal or encouraging persuasion (Falco \& Summers, 2017). Students are 
expected to view and find out what is special or unique about them through career guidance. They encourage individuals or groups to develop their talents for future career use (Kunnen, 2014). In line with Reisberg et al., (2012) that career guidance plays a role so that students understand the various career options available to them, broaden students' knowledge of work, and help recognize that they have the ability and interest in carrying out a set of skills required in various types of work.

However, this research has shown that fieldwork practice significantly affects self-efficacy, and H6 was supported. This empirical finding is consistent with previous studies that indicated that fieldwork practice programs help students better understand themselves and increase their self-efficacy (Raelin et al., 2015; Freudenberg, Cameron, \& Brimble, 2010). Hodges (2018) explains that a person can develop a strong belief in self-efficacy by gaining success due to his own experiences. The achievement of performance forms Selfefficacy. Students' success in their fieldwork practices appears to increase their confidence in performing various specific behaviors to deal with workplace requirements (Reisberg et al., 2012). Bandura (2012) states that someone could develop self-efficacy through four main steps: mastery experience, vicarious experience, social persuasion, and physiological states. These four main steps can be taken through learning programs integrated with work (Freudenberg et al., 2012; Freudenberg et al., 2010).

The present study showed no significant effect of emotional intelligence on self-efficacy, and H7 was not supported. It means that emotional intelligence does not contribute to self-efficacy among Beauty students. The non-significant of these results may be due to students' emotional intelligence level being insufficient for their sense of self-efficacy. Tabatabaei et al. (2013) revealed that if emotions are correctly directed, it can lead to the more outstanding commitment and self-efficacy. In other words, a higher level of emotional intelligence, especially in managing one's emotions, has led individuals to greater self-confidence in displaying skills and behaviors related to work ability (Coetzee \& Beukes, 2010). Therefore, emotional intelligence needs to be integrated into learning to develop student self-efficacy. Besides, Bandura (2012) revealed that although students obtained information to assess their self-efficacy from four sources, students' performances on past assignments and modeling seemed to be the most influential sources. So that efforts to increase student self-efficacy must also pay attention to other factors involved in developing a sense of selfefficacy.

\section{Conclusions}

There are some significant research findings in this study. Firstly, the present study found no significant effect of career guidance, fieldwork practice, emotional intelligence, and self-efficacy towards employability skills among Beauty students. Secondly, career guidance and emotional intelligence have no significant effect on self-efficacy. However, fieldwork practice has a significant effect on the self-efficacy of Beauty students. This study seeks to develope employability skills for vocational high school students, particularly in the Beauty Expertise Program. This study's results are expected to provide a new perspective for vocational education to increase students' employability skills by integrating career guidance, emotional intelligence, and self-efficacy into educational strategies. So that students are more to face the challenges they will face in the world of work. Moreover, employability cannot be a purely individual or institutional achievement, rather an outcome of the involved stakeholders' joint efforts, including students, graduates, academics, program coordinators, employers, and policymakers (Yulia \& Yuzhuo, 2015). This study has its own limitations and weakness. The Covid-19 pandemic's existence made data collection not optimal because it could only be done online. Researchers could not conduct direct interviews with students to find out more deeply why the research results rejected all the hypotheses proposed in this study. Therefore further research needs to fix this weakness. The present study findings used a small number of samples, and the data was collected in the Gerbang Kertosusilo area only. Future studies recommend adding a larger sample size so that the results obtained are more optimal because they can be generalized over a wider area.

\section{Acknowledgement}

The authors would like to thanks the supervisors from Postgraduate of State University of Surabaya for their assistance in the completed this study.

\section{Author's Contributions}

All authors discussed the results and contributed to from the start to final manuscript.

\section{Conflict of Interest}

The authors declare that they have no competing interests. 


\section{References}

Afujo, B. I. (2013). Challenges of youth unemployment in Nigeria: Effective career guidance as a panacea. International Multidisciplinary Journal, Ethiopia, 7(28), 307-321. https://doi.org/10.4314/afrrev. v7i1.21

Amiruddin, Sunardi, \& Irmayanti. (2013). Mengembangkan employability skills siswa SMK melalui project based learning. In Seminar Nasional Fakultas Teknik Universitas Negeri Makassar (pp. 416-423).

Anas, I., \& Hamzah, S. R. (2017). Conceptual study on the enhancement of employability among undergraduates in work-based learning settings. International Journal of Academic Research in Business and Social Sciences, 7(Special), 65-79. https:// doi.org/10.6007/ IJARBSS/v7-i14/3652

Bandura, A. (Ed.). (1995). Self-efficacy in changing societies. Cambridge: Cambridge University Press. https://doi.org/10.1109/EVER.2017. 7935960

Bandura, A. (1997). Self-efficacy: The exercise of control. New York: W. H. Freeman and Company.

Bandura, A. (2006). Guide for constructing self-efficacy scales. In F. Pajares \& T. Urdan (Eds.), Self-efficacy belief of adolescents (pp. 307-337). New York: Information Age Publishing.

Bandura, A. (2012). On the functional properties of perceived self-efficacy revisited. Journal of Management, 38(1), 9-44. https://doi.org/10. 1177/0149206311410606

Berntson, E., Naswall, K., \& Sverke, M. (2008). Investigating the relationship between employability and self-efficacy: A cross-lagged analysis. European Journal of Work and Organizational Psychology, 17(4), 413-425. Retrieved from https://doi.org/10.1080/13594320 801969699

Beukes, C. J. (2010). Employability and emotional Intelligence of the individual within the school-to- work transition phase. University of South Africa.

BNSP. (2017). Skema sertifikasi KKNI level II pada kompetensi keahlian kecantikan kulit dan rambut. Badan Nasional Sertifikasi Profesi (BNSP).

BPS. (2020). Berita resmi statistik: Keadaan ketenagakerjaan Jawa Timur, Februari 2020.

Brewer, L. (2013). Enhancing youth employability: What? Why? and How? Guide to core work skills. Geneva: ILO.

Buraga, J. G., \& Caballero, R. T. (2018). Effectiveness of the career guidance program and the employability of the graduates of Isabela State University during the school year 2010-2015. Researchers World:Journal of Arts, Science and Commerce, 9(1), 127. https://doi.org/10.18843/rwjasc/v9i1/16

Cahyono, S. D. (2014). Kontribusi minat kerja dan bimbingan karir terhadap kesiapan memasuki dunia kerja. E-Jurnal Pendidikan Teknik Mesin, 2(3), 193-200.

CBI. (2011). Working towards your future. London: CBI. Retrieved from https://www.nus.org.uk/Global/CBI_NUS_Employability report_May 2011.pdf

Chow, H. J., Wong, S. C., \& Lim, C. S. (2019). Examining mediating role of self-efficacy on undergraduates' perceived employability. International Journal of Academic Research Business and Social Sciences, 9(6), 14-38. https://doi.org/10.6007/IJARBSS/v9-i6/5929

Coetzee, M., \& Beukes, C. J. (2010). Employability, emotional intelligence and career preparation support satisfaction among adolescents in the school-to-work transition phase. Journal of Psychology in Africa, 20(3), 439-446.

Dwesini, N. F. (2017). The role of work-Integrated learning (WIL) in enhancing employability skills: Graduate perspectives. African Journal of Hospitality, Tourism and Leisure, 6(2), 1-9. Retrieved from www.ajhtl.com

Eccles, S., \& Renaud, V. (2018). Building students' emotional resilience through placement coaching and mentoring. In D. Morley (Ed.), Enhancing Employability in Higher Education through Work Based Learning (pp. 153-172). Guildford: Palgrave Macmillan.

Eden, S. (2017). Out of the comfort zone: Enhancing work-based learning about employability through student reflection on work placements. Journal of Geography in Higher Education, 38(2), 266-276. https:// doi.org/10.1080/03098265.2014.911826

Edwards, M. (2014). The impact of placements on students' self-efficacy. Higher Education, Skills and Work-Based Learning, 4(3), 228-241. Retrieved from https://doi.org/10.1108/HESWBL-05-2014-0015

Falco, L., \& Summers, J. (2017). Improving career decision self- efficacy and STEM self-efficacy in high school girls: Evaluation of an intervention. Journal of Career Development, 20(10), 1-15. https:// doi.org/10.1177/0894845317721651

Fitriyanto, M. N., \& Pardjono, P. (2019). Factors affecting the employability skills of vocational students majoring mechanical engineering. Jurnal Pendidikan Vokasi, 9(2), 132-140. https://doi.org/10.21831/ jpv.v9i2.24420

Freudenberg, B., Brimble, M., \& Cameron, C. (2010). Where there is a WIL there is a way. Higher Education Research $\mathcal{E}$ Development, 29(5), 575-588. https://doi.org/10.1080/07294360.2010.502291

Freudenberg, B., Brimble, M., Cameron, C., MacDonald, K., \& English, D. (2012). I am what I am, am I? The development of self-efficacy through work integrated learning. The International Journal of Pedagogy and Curriculum, 19(3), 89136. 
Freudenberg, B., Cameron, C., \& Brimble, M. (2010). The importance of self: Developing students' self efficacy through work integrated learning. The International Journal of Learning, 17(10), 479-496. Retrieved from http:/ /ijl.cgpublisher.com/product/pub.30/prod.2980

Geiser, C. (2013). Data analysis with Mplus. Methodology in the social sciences. New York: The Guilford Press. Retrieved from http:/ / uml.idm.oclc.org/login?url=https://search.proquest.com/docview/1284064362?accountid=14569

Ghozali, I. (2017). Structural equation modeling konsep dan aplikasi dengan program AMOS 24. Semarang: Universitas Diponegoro.

Goleman, D. (2001). Emotional intelligence: Issues in paradigm building. In C. Cherniss \& D. Goleman (Eds.), The Emotionally Intelligent Workplace (pp. 1-13). San Francisco: Jossey-Bass.

Goleman, D. (2009). Emotional intelligence: Why it can matter more than IQ. London: Bloomsbury Publishing.

Guile, D., \& Griffiths, T. (2016). Learning through work experience. Journal of Education and Work, 14(1), $113-131$. https://doi.org/10.1080/ 13639080020028738

Hamalik, O. (2009). Pengembangan SDM pelatihan ketenagakerjaan pendidikan terpadu. Jakarta: Bumi Aksara.

Hanafi, I. (2012). Re-orientasi keterampilan kerja lulusan pendidikan kejuruan. Jurnal Pendidikan Vokasi, 2(1), $107-116$.

Harry, T., Chinyamurindi, W. T., \& Mjoli, T. (2018). Perceptions of factors that affect employability amongst a sample of final-year students at a rural South African university. SA Journal of Industrial Psychology, 44(0), 1-10. https://doi.org/10.4102/ sajip.v44i0.1510

Harvey, L. (2003). Transitions from higher education to work: a briefing paper prepared by Lee Harvey (Centre for Research and Evaluation, Sheffield Hallam University), with advice from ESECT and LTSN Generic Centre colleagues. Retrieved from http:/ / bit.ly/oeCgqW

Helyer, R., \& Lee, D. (2015). The role of work experience in the future employability of higher education graduates. Higher Education Quarterly, 68(3), 348-372. https://doi.org/10.1111/hequ.12055

Herwina, W., Madjid, H. A., \& Daniel, H. (2018). Pengembangan model pembelajaran terintegrasi soft skill dan hard skill pada lembaga kursus kecantikan. Jurnal Ilmiah VISI PGTK PAUD Dan DIKMAS, 13(1), 37-47.

Hodges, C. B. (Ed.). (2018). Self-Efficacy in instructional technology contexts. Switzerland: Springer. https://doi.org/10.1007/978-3-319- 99858-9

Husain, M. Y., Mokhtar, S. B., Ahmad, A. A., \& Mustapha, R. (2010). Importance of employability skills from employers' perspective. Procedia - Social and Behavioral Sciences, 7(2), 430-438. https://doi.org/10.1016/j.sbspro.2010.10.059

Jameson, A., Carthy, A., Mcguinness, C., \& Mcsweeney, F. (2016). Emotional intelligence and graduates - employers ' perspective s. Procedia - Social and Behavioral Sciences, 228, 515-522. https://doi.org/10.1016/j.sbspro.2016.07.079

Jayawardena, L. N. A. C., \& Gregar, A. (2013). Enhancing the employability of high school graduates: Impact of emotional intelligence. WSEAS Transactions on Business and Economics, 10(2), 89-96.

Juhdi, N., Wan, F. P., Othman, N. A., \& Moksin, H. (2010). Factors influencing internal and external employability of employees. business and economics Journal, BEJ-11, 1-10.

Kannaiah, D., \& Shanthi, R. (2015). A study on emotional intelligence at work place. European Journal of Business and Management, 7(24), 147-155. Retrieved from www.iiste.org

Kunnen, E. S. (2014). The effect of a career choice guidance on self-reported psychological problems. Frontiers in Psychology, 5, 1-8. https://doi.org/10.3389/fpsyg.2014.00547

Kurniawati, A., \& Arief, S. (2016). Pengaruh efikasi diri, minat kerja, dan bimbingan karir terhadap kesiapan kerja siswa program keahlian akutansi. Economic Education Analysis Journal, 5(1), 363-376.

Loan, D. T. B., \& Van, N. T. (2015). Career guidance in secondary schools - A literature review and strategic solutions for Vietnamese rural areas. American International Journal of Social Science, 4(5), 135-143.

Maddux, J. E. (1995). Self-efficacy, adaptation, and adjustment: theory, research, and application. (J. E. Maddux, Ed.), The Plenum series in Social/Clinical psychology. New York: Springer Science+Business Media. https://doi.org/10.1007/978-1-4419-6868-5

Martínez-roca, C., Martínez, M., \& Pineda, P. (2014). The role of career guidance in the development of competences for socially fair employability. Procedia - Social and Behavioral Sciences, 139(0), 343-350. https://doi.org/10.1016/j.sbspro.2014.08.009

Mayer, J. D., Caruso, D. R., \& Salovey, P. (2016). The ability model of emotional intelligence: Principles and updates. Emotion Review, 8(4), 290-300. https://doi.org/10.1177/1754073916639667

Munadi, S., Widarto, Yuniarti, N., Jerusalem, M. A., Hermansyah, \& Rahmawati, F. (2018). Employability skills lulusan SMK dan relevansinya terhadap kebutuhan dunia kerja. (M. Herdyka, M. A. Majid, \& Ari, Eds.) (1st ed.). Yogyakarta: Direktorat Pembinaan Sekolah Menengah Kejuruan.

Mutoharoh, A. K., \& Rahmaningtyas, W. (2019). Pengaruh praktik kerja industri, lingkungan keluarga, bimbingan karier dan motivasi kerja terhadap kesiapan kerja. Sains: Jurnal Manajemen Dan Bisnis, 12(1), 38-59.

Navas, M. del C. O. (2014). The improvement of employability among Higher Education students: the use of emotional intelligence as an educational strategy. Procedia - Social and Behavioral Sciences, 139, 380-386. 
https://doi.org/10.1016/j.sbspro.2014.08.021

Ojonugwa, O. I., Hamzah, R., Bakar, A. R., \& Rashid, A. M. (2015). Evaluating self-efficacy expected of polytechnic engineering students as a measure of employability. International Journal of Education $\mathcal{E}$ Literacy Studies, 3(3), 2430. https://doi.org/10.7575/ aiac.ijels.v.3n.3p.24

Oliver, B. (2015). Redefining graduate employability and work-integrated learning: Proposals for effective higher education in disrupted economies. Journal of Teaching and Learning for Employability, 6(1), 56-65.

Pathak, A., Shankar, S., \& Tewari, V. (2018). Impact of emotional intelligence on employability of IT professionals. Management Insight, 14(1), 14-21. https:// doi.org/10.21844/mijia.14.01.4

Pegg, A. A., Waldock, J., Hendy-isaac, S., \& Lawton, R. (2012). Pedagogy for employability. 1-904190-80-4: The Higher Education Academy.

Pitan, O. S., \& Atiku, S. O. (2017). Structural determinants of students' employability: Influence of career guidance activities. South African Journal of Education, 37(4), 1-13. https://doi.org/10.15700/ saje.v37n4a1424

Pool, L. D., \& Sewell, P. (2007). The key to employability: developing a practical model of graduate employability. Education + Training, 49(4), 277-289. https://doi.org/10.1108/00400910710754435

Potgieter, I., \& Coetzee, M. (2013). Emotional intelligence as a predictor of postgraduate students' psychosocial employability attributes. Journal of Psychology in Africa, 23(2), 187-194.

Quiring, S. Q., Boys, S. K., \& Harris, E. M. (2017). The role of self-efficacy in employability: implications for pedagogical change. Thurgood Marshall Law Review, 43(1), 533-550. Retrieved from https://www.researchgate.net/publication/333390080_The_Role_of_SelfEfficacy_in_Employability_Implications_for_Pedagogical_Change

Raelin, J., Bailey, M., Hamann, J., Pendleton, L., Reisberg, R., \& Whitman, D. (2015). The role of work experience and selfefficacy in STEM student retention. Journal on Excellence in College Teaching, 26(4), 29-50.

Rasul, M. S., Rauf, R. A. A., Mansor, A. N., Yasin, R. M., \& Mahamod, Z. (2013). Graduate employability for manufacturing industry. Procedia - Social and Behavioral Sciences, 102, 242-250. https://doi.org/ 10.1016/j.sbspro.2013.10.739

Rawat, R., \& Sharma, R. (2018). Is psychological capital related to employability skills of graduate students? Journal of General Management Research, 5(2), 39-54. Retrieved from https://pdfs. semanticscholar.org/a6bb/72fa204f58050942f7b83b818e5655db3173.pdf

Reisberg, R., Raelin, J. A., Bailey, M. B., Whitman, D. L., Hamann, J. C., \& Pendleton, L. K. (2012). The effect of cooperative education on the self-efficacy of students in undergraduate engineering. In ASEE Annual Conference and Exposition, Conference Proceedings. American Society for Engineering Education.

Restubog, S. L. D., Florentino, A. R., \& Garcia, P. R. J. M. (2016). The mediating roles of career self-efficacy and career decidedness in the relationship between contextual support. Journal of Vocational Behavior, 77(2), 186-195. https://doi.org/10.1016/j.jvb.2010.06.005

Rhode, K. M. (2010). The effect of career counseling on the self-efficacy and career maturity of residential juvenile offenders. Texas Tech University.

Robertson, P. J. (2013). The well-being outcomes of career guidance. British Journal of Guidance E Counselling, 41(3), 254266.

Rosmawati, P., \& Usman, O. (2019). Effect of self-efficacy, working interest and career guidance to working readiness on vocational high school student majoring in office administrative in the South Jakarta. SSRN eJournals, (1), 1-12. https://doi.org/10.2139/ssrn.3415368

Rufai, A. U., Bakar, A. R. Bin, \& Rashid, A. B. M. (2015). Developing a sustainable practical model of graduate employability for Higher Education. International Journal of Education \& Literacy Studies, 3(1), 42-51. https://doi.org/10.7575/aiac.ijels.v.3n.1p.42

Serrat, O. (2009). Understanding and developing emotional intelligence. Knowledge Solutions, (49), 1-9.

Singh, D. (2006). Emotional intelligence at work: A professional guide (Third). New Delhi: Response Book.

Subekti, S., \& Ana. (2018). Developing employability skills of vocational high school students in implementing work based learning (WBL). In Proceedings of the 1st International Conference on Culinary, Fashion, Beauty, and Tourism (pp. 11-12). Padang.

Sunardi, Purnomo, \& Sutadji, E. (2016). Pengembangan employability skills siswa SMK ditinjau dari implementasi pendekatan saintifik. Jurnal Pendidikan: Teori, Penelitian, Dan Pengembangan, 1(7), 1391-1398.

Supriatna, M., \& Budiman, N. (2010). Bimbingan karier di SMK. Bandung: Departemen Pendidikan Nasional Universitas Pendiikan Indonesia. Retrieved from http://file.upi.edu/Direktori/FIP/JUR._PSIKOLOGI_ PEND_DAN_BIMBINGAN/197102191998021-NANDANG_BUDIMAN/BIMBINGAN_KARIER_DI_SMK.pdf

Tabatabaei, S., Jashani, N., Mataji, M., \& Amir, N. (2013). Enhancing staff health and job performance through emotional intelligence and self-efficacy. Procedia - Social and Behavioral Sciences, 84, 1666-1672. https://doi.org/10.1016/j.sbspro.2013.07.011 
Tentama, F., \& Merdiaty, N. (2020). Analysis of factors that affect employability and its implications. Humanities and Social Sciences Reviews, 8(3), 238-254. https://doi.org/10.18510/hssr.2020.8325

Terzaroli, C., \& Oyekunle, Y. (2019). Career service as a measute to support employability: A comparison between University of Florence and The University of Lagos. Studies in Adult Education and Learning, 25(1), 89-110. Retrieved from http://dx.doi.org/10.4312/ as.25.1.89-110

Van de Hof, R. (2015). Self-esteem, self-efficacy and employability among disadvantaged youth in Orange Farm, Johannesburg. Utrecht University.

Wang, J., \& Wang, X. (2012). Structural equation modeling: Applications using Mplus. United Kingdom: JohnWiley \& Sons Ltd.

Wang, Y. (2012). Education in a changing world: Flexibility, skills, and employablity (Vol. 69104). Washington: The World Bank. Retrieved from www.worldbank.org

Weldon, A., \& Ngo, J. K. (2019). The effects of work-integrated learning on undergraduate sports coaching s tudents ' perceived self-efficacy. International Journal of Work-Integrated Learning, 20(3), 309-319.

Winkel, W. S., \& Hastuti, M. M. S. (2015). Bimbingan dan konseling di institusi pendidikan. Yogyakarta: Media Abadi.

$\mathrm{Xu}, \mathrm{Y}$. (2013). The characteristic of college students' employability and its relationship with emotional intelligence. Journal of Chemical and Pharmaceutical Research, 5(12), 70-76. Retrieved from www. jocpr.com

Yahya, M., Iskandar, S., \& Sunardi. (2017). Technical skills and employability skills of vocational high school students in Indonesia. Journal of Scientific Research and Studies, 4(6), 148-155.

Yorke, M. (2010). Employability: aligning the message, the medium and academic values. Journal of Teaching and Learning for Employability, 1(1), 2-12.

Yorke, M., \& Knight, P. (2003). The undergraduate curriculum and employability.

Yulia, S., \& Yuzhuo, C. A. I. (2015). Factors affecting the employability of international graduates. International Scientific Journal of Universities and Leadership, (1), 24-30.

Zeidner, M., Matthews, G., \& Roberts, R. D. (2009). What we know about emotional intelligence: How it affects learning, work, relationship, and our mental health. London: Massachusetts Institute of Technology Press. 